\title{
Relationships Between Metacognitive Strategies and Characteristics of Professional Tour Guide Trainees in English for Tourism
}

Malinee Phaiboonnugulkij*

English Curriculum, Faculty of Humanities and Social Sciences, Nakhon Ratchasima Rajabhat University, Thailand

Corresponding Author: Malinee Phaiboonnugulkij, E-mail: malineerabbbit@hotmail.com

\begin{abstract}
ARTICLE INFO
Article history

Received: February 16, 2018

Accepted: April 26, 2018

Published: June 30, 2018

Volume: 9 Issue: 3

Advance access: May 2018

Conflicts of interest:

None Funding: YES

The research is financed by

Faculty of Humanities and

Social Sciences Nakhon

Ratchasima Rajabhat University

ABSTRACT

The objectives of this study are to investigate and compare the total and individual metacognitive strategies used by professional tour guides in four English for Domestic Tourism lessons, and to explore the relationships between the use of metacognitive strategies in these lessons and characteristics of professional tour guide trainees. A total of eighteen professional tour guide trainees participated in this study and they were classified into groups from their proficiency levels in English, duration in English language study and the level of responsibility of their current jobs. The research instruments were a metacognitive strategy questionnaire, strategy coding scheme, English for Domestic Tourism lessons and English for Domestic speaking test and rating scale. Chi-square, One-way Analysis of Variance (ANOVA), frequency, means, standard deviations and the qualitative content analysis from the questionnaires and coding scheme were used in the data analysis. The results show no significant differences in the use of both the total and individual metacognitive strategies in four lessons. However, there are significant relationships at the. 05 level between proficiency level and goal setting and control of linguistic execution strategies. There are also significant relationships between duration of English language study and planning strategies and control of linguistic execution. The substantive insights from a qualitative content analysis show the prominent ways of how characteristics affect the strategy use of particular groups which should be included in both teacher and students' training on how to make use of these higher order thinking to effectively teach and learn English language.
\end{abstract}

Key words: Characteristics, Metacognitive Strategies, Speaking Ability, English for Tourism, Tour Guides, English proficiency Levels, English Language Studies, English for Specific Purposes

\section{INTRODUCTION}

Metacognitive strategies are significant in English language learning since they enable the learners to control, regulate, monitor and evaluate their learning effectively (Oxford 2003). Metacognitive strategies are an essential part of strategic competence in a study of Douglas (2000) Language for Specific Purposes' ability (LSP). In this LSP's ability, strategic competent acts as the mediator that relates language specific background knowledge and the language knowledge which results in LSP ability. Metacognitive strategies in LSP context assist the learners to self- assess their learning, set their goal, plan their performance and control the linguistic execution. These strategies are hierarchically employed by the learners to formulate and produce the language. In this study English for Tourism is part of LSP that poses specific features of language use in Tourism with precise technical terms and specific background knowledge in the field (Douglas, 2000).

From the integral and significant role of metacognitive strategies in English language learning, they are widely in- vestigated in a vast number of issues with varied results. A large number of studies explore the factors affecting the use of metacognitive strategies in English language learning. These factors include English language proficiency levels, gender, learners' belief, duration in English language study, learning style and motivation of the learners. They are claimed to have an impact on choice of strategy used by previous studies (Deneme, 2008, Khamkhien, 2010 and Oxford, 2003). These factors are learners' characteristics in the present study that have potential impacts on choice of metacognitive strategies.

Proficiency level is one of the leading factors that has great impact on choice of metacognitive strategy use and has been studied with a large number of studies, and the vast numbers of the results are positive with more advanced students: the intermediate and the high-proficiency group (Phaiboonnugulkij, 2016, Kunasaraphan, 2015, Phaiboonnugulkij and Prapphal, 2013, and Lui and Feng, 2011). These findings show that the high proficiency groups are able to assess, plan, monitor and evaluate their learning effectively towards their learning needs. The way they utilize their metacogni- 
tive strategies varies in different factors including learners' characteristics, specific features of the lessons and contexts. However, Lam (2010) does not find any significant difference in the metacognitive strategies across groups of 40 students in Hong Kong. It is suggested in this study that it is ultimately important to raise general strategic awareness through guiding learners' attention to their own strategies.

Gender and belief are both significant factors concerning choice of metacognitive strategies used, the results are not significantly different in these studies between the two genders (Salahshour, Sharifi and Salahshour, 2013, Zhou 2018, Radwan, 2011). These studies indicate that metacognitive strategies are preferred by particular gender as males in the study of Radwan (2011) and Salahshour, Sharifi and Salahshour (2013). Adding to this, Zhou (2018) recently investigated both the relationship of gender and belief on learning strategies, including metacognitive strategies with 105 third year English majored University students in China. The results from Pearson correlation analysis show that English learning beliefs and learning strategy are closely related. To be precise, the general learning belief has a significant correlation with metacognitive strategies, meaning that the higher level of their learning belief, the more frequent the use of metacognitive strategies.

This includes duration of English language learning that is investigated by Radwan (2011). The author studies the relationship between proficiency and gender on choice of language learning strategies by 128 English majored students at the university level in Oman. In general, freshmen report the higher means of all strategies than the remaining three groups. It is purported that the more advanced a student is in the target language the need to consciously use these strategies becomes more deliberate, resulting in their learning strategies becoming less necessary. They may internalize these strategies and these strategies were autonomously processed, thus the senior learners reported fewer strategies than that of the freshmen group. Metacognitive strategies are also explored from their instructional effects on many skills. Some studies show positive effects of metacognitive instruction that can increase students' achievement scores (Pitenoee, Modaberi and Ardestani, 2017 and Bozorgian and Alamdari, 2018). However, some studies do not find any effects of teaching these higher-order thinking strategies on students' achievement scores (Lam, 2010).

This present study thus includes characteristics of learners as the factors that have affected on the choice of metacognitive strategies use. Characteristics of the learners are from the major factors found in previous literature review, and they include proficiency level, duration in English language study and types of job. Although a large number of studies explored the relationship between these factors and the use of metacognitive strategies, additional factors, particularly types of job of the learners should be explored, and it is emphasized in this study. Additionally, research rarely focuses on the utilization of these metacognitive strategies in English for Tourism learning, which it is the focus of this study. From these significances, this study aims to investigate and compare total and individual metacognitive strategies used by professional tour guide trainees in four English for Tourism lessons; and explore the relationships between the use of metacognitive strategies in these lessons and characteristics of professional tour guide trainees.

\section{METHODOLOGY}

\section{Participants}

The population in this study was the group of professional tour guides trainees who took the professional tour guide training course in the first semester of the academic year 2016 at Nakhon Ratchasima Rajabhat University (NRRU). The sample in this study was randomly selected, and they consisted of eighteen professional tour guide trainees who were going to receive a bronze card tour guide license granted by Tourism Authority of Thailand after they have passed all the requirement including English for Tourism course. They were classified into two groups based on their proficiency level using a speaking test in English for Tourism, an adjusted version of Web-based Speaking Test in English for Tourism (WBST-EFT) (Phaiboonnugulkij and Prapphal, 2013).

Participants with the band scores from 2.20 and 2.45 were assigned into a high- proficiency group, whereas those with band scores ranged from band 1.20 to 1.60 were in a low-proficiency group. For the duration of English language study, the participants were divided into three subgroups: Group one) less than 10 years, Group two) between 11 - 20 years and Group three) more than 21 years. Finally, they were re-grouped into four sub-groups based on types of their current jobs: Group one) professional tour guides, Group two) marketing manager, Group three) tourism staff and Group four) students.

\section{Instrumentation}

The instrumentation in the present study consists of four major instruments as follows.

\section{English for domestic tourism speaking test and the rating scale}

An English for Domestic Tourism speaking test was part of the final-achievement test for the professional tour guide training course at NRRU. It consisted of four test tasks: Presenting general information about Thailand, Buddha images, Thai history and attractions in the north of Thailand. Trainees were required to take the oral test with the researcher who was the lecturer in the course. They were required to give brief information about Thailand, then present one attitude and poster of the famous Buddha image. Finally, they would give a guided tour by selecting one attraction in the north along with giving details of the history of that attraction. Photographs of both the Buddha image and the attraction were allowed in the test to simulate the real scene of the tour guide. Their responses were rated later by two raters for reliability and validity of the scores.

The rating scale for the test was an analytical rating scale with the criteria on range and accuracy in linguistic components and content, and fluency of speaking performances. Compo- 
nents were content knowledge, accuracy in vocabulary and gram-matical structure and fluency of speech performances. Each component combined five ability bands, starting from band level 0 (a very poor user), 1(a beginner), 2 (a fair user), 3 (a good user) to 4 (a very good user). The band scores came from a summation of the average scored from two raters. The rater training was arranged before the main study for the consistency and reliability of the scoring procedure. This analytical rating scale was an adapted version from a rating scale of A web-based speaking test in English for Tourism (WBST-EFT) (Phaiboon-nugulkij and Prapphal, 2013; Phaiboonnugulkij, 2015).

\section{English for domestic tourism lessons}

English for Domestic Tourism lessons were made up of four main lessons: General information about Thailand, Presenting Buddha images, Thai history and Presenting attractions in the north of Thailand. These lessons were taught in the professional tour guide training course for one semester. General information about Thailand required the trainees to present related details about Thailand to the foreign tourists and Presenting Buddha images dealt with identifying postures and attitudes of Buddha images and described these images' specific details. Thai history required trainees to identify and give specific details about Thai historical periods to the tourists.

The last lesson, presenting attractions in the north of Thailand requires the trainees to describe specific details about major constructions and important things inside the attractions in the north of Thailand, and trainees were required to give a guided tour about these attractions. These lessons were parts of the supplementary teaching materials for the course of 207363 English for Domestic Tourism for the Bachelor of Arts Students at NRRU. These lessons incorporated a wide range of teaching approaches and learning activities with the focus on cooperative learning, project-based learning, picture-word inductive method and social constructivism. The lessons were validated by five experts in the fields for content and construct validity at the value of 0.75 .

\section{Metacognitive strategies questionnaire}

The questionnaire on the use of metacognitive strategies was comprised of three parts: demographic information, frequency the individual uses metacognitive strategies and an open-ended section. Demographic information deals with the trainees' characteristics including their working position, education and duration in English language study. The second part was about the how the individual uses metacognitive strategies in each lesson, totaling four lessons.

In this part, trainees were required to write down the frequency of the individual metacognitive strategies and how they use them in their learning through the provided area in each lesson. Finally, the open-ended section required the trainees to add more information about their use of metacognitive strategies.

\section{Coding scheme}

In this study, a metacognitive strategies coding scheme is identified that underpins strategic competence from the LSP ability notion of Douglas (2000). Metacognitive strategies or the higher order thinking were used as the mediator to relate between LSP background knowledge and the English language knowledge in both speech formation and production. The focus was on how the trainees employed these metacognitive strategies in learning English for Tourism course for their speaking performances, specifically in learning the four lessons (Phaiboonnugulkij, 2015).

Metacognitive strategies consist of four independent strategies: assessment, goal setting, planning, and control of linguistic execution. An assessment strategy is used to determine what is needed, what one has to work with and how well one has done to achieve the tourism communicative goal and objective of the lesson. It is followed by the use of goal setting strategy to identify the contents and English language in the lessons and decide what one should do to achieve the objectives of the lesson. Planning strategy is used to think of how to use the existing English language knowledge and tourism related content knowledge to achieve the objective of the lesson and communicative goal in tourism context. Finally, control of linguistic execution strategy is employed to carry out the response by combining content knowledge and language knowledge to form the answer.

After drafting the definitions of metacognitive strategies, the questionnaires were created to obtain the frequency of, and in-depth information on, how trainees used metacognitive strategies in four lessons. This coding scheme was validated and piloted before the main study. Then the coder training was arranged to transcribe and categorize the reported metacognitive strategies by two coders to ensure the consistency and validity of the coding method. A researcher was one coder and another was the English for Domestic Tourism lecturer at NRRU, holding an M.A. in English language studies with five years teaching experience.

All the four instruments in the present study were validated by the three experts in the field with the content and construct validity value of 0.75 to 1.00 using item-objective congruence table (IOC), and reliability value ranged from 0.75 to 0.91 . The exception was for the lesson plan that five experts were required as these lessons were part of the supplementary teaching material to submit for the assistant professor position.

\section{Data Collection}

Trainees were firstly required to study the four lessons. Then they were asked for permission to participate in a metacognitive strategies report session. At the end of each lesson, they were asked to complete the questionnaire about the frequency and how they used these metacognitive strategies in their learning. They were required to write in detail of how to use these strategies in the questionnaires providing concrete examples in each lesson and sub-strategies.

Finally, all the data on the frequency was statistically analyzed, and the use of metacognitive strategies in the lessons from the questionnaires was transcribed into the coding scheme by the coders. 


\section{Data Analysis}

The data is analyzed in the following procedures.

2.4.1. To achieve first objective, One-way Analysis of Variance (ANOVA) was used to investigate the differences on the total and individual metacognitive strategies in the four lessons. This included descriptive statistics, mean scores and standard deviations.

2.4.2. To achieve the second objectives, Chi-square was used to indicate the relationship between characteristics of the professional tour guide trainees and the use of metacognitive strategies in four lessons. This included the scales presenting frequency of reported metacognitive strategies.

2.4.3. Qualitative content analysis from reported metacognitive strategies were analyzed and transcribed from the coding scheme to see how each group used the metacognitive strategies in the lesson.

\section{RESULTS AND DISCUSSIONS}

\section{Use of Metacognitive Strategies in Four English for Tourism lessons}

\section{Total use of metacognitive strategies in four English for tourism lessons}

Table 1 shows that there is no significant difference in the use of total metacognitive strategies between the high- and low-proficiency professional tour guide trainees in all four English for Domestic Tourism lessons at the.05 level. In other word, the two proficiency groups do not differently use total metacognitive strategies in four lessons. Although no significant difference is found across the four lessons, the most observable difference is in lesson one, $F(1,16)=3.86, p=.07)$ whereas the least difference is in lesson four, $F(1,16)=11, p=.74)$. Means differences in the total use of metacognitive strategies between two proficiency groups are displayed in the following table 1 .

Table 2 shows the differences in the mean scores of the total metacognitive strategies between the high- and low-proficiency professional tour guide trainees in all four English for Domestic Tourism lessons. The high proficiency group report higher usage of total metacognitive strategies than the low proficiency group across four English for Domestic Tourism lessons.

Among the four lessons, it is noticeable that the most different mean is in lesson one: General information about Thailand, $(\mathrm{MH}=4.02$, S.D. $=.71, \mathrm{ML}=3.38$, S.D. $=68)$ whereas the least different is in lesson four: Presenting the northern attractions in Thailand that the two reported almost the similar means $(\mathrm{MH}=3.25$, S.D. $=1.32, \mathrm{ML}=3.05$, S.D. $=1.15)$. The results indicate that the two groups employ most different total metacognitive strategies in lesson one, but they report almost similar metacognitive strategies in lesson four. The differences in the use of four individual metacognitive strategies between the two proficiency groups are displayed in the following part.

\subsubsection{Individual metacognitive strategies used by professional tour guide trainees in four English for Tourism lessons}

Table 3 illustrates the differences in the use of four individual metacognitive strategies between the two proficiency groups. Generally, there is no significant difference between the two proficiency groups in the use of four individual metacognitive strategies at the 0.05 level.

The most noticeable difference is found in control of linguistic execution, $F(1,16)=1.76, p=.20)$. Adding to this, the least difference between the two groups is in goal setting strategy, $F(1,16)=.43, p=.51)$. In other words, the most different use of individual metacognitive strategies is control of linguistic execution strategy, but the least difference is the use of goal setting strategy.

Results of the present study on no significant difference in the use of metacognitive strategies across proficiency levels contradict the previous studies (Kunasaraphan, 2015, Pitenoee, Modaberi and Ardestani, 2017 and Bozorgian and Alamdari, 2018). These studies find that the high proficiency group significantly and differently report metacognitive strategies as the low proficiency group. Kunasaraphan (2015) explores the English language learning strategy use and the proficiency level in 300 first year university students in Thailand. The findings also show a significant difference in the strategy use and the proficiency level, meaning that different proficiency groups use significant different frequency of strategies. Students with low, medium and high level reported significantly different use of metacognitive strategies. Out of the three groups, the high-level group used strategies with the highest frequency, and of all the strategies metacognitive strategies are found to be favored the most by all groups.

Adding to the results from both Pitenoee, Modaberi and Ardestani (2017) and Bozorgian and Alamdari (2018) indicate the significant effect of teaching metacognitive strategies across skills in writing and listening. This study investigates the effect of both metacognitive and cognitive strategies on the writing content of 75 Iranian intermediate EFL students. The findings show that there are significant differences between the three groups, $\mathrm{F}(2,72)=0.6 .22, p=0.05$. Specifically, students who use metacognitive strategies achieve the highest scores in English content writing, $(\mathrm{M}=26.84$, S.D.= 1.17) and higher scores than the group which is instructed with cognitive strategies, $(M=25.04$, S.D. $=1.36)$. This indicates the relationship between metacognitive strategies and students' content writing achievements.

Similarly, Bozorgian and Alamdari (2018) also explores the effect of teaching metacognitive strategies on students' listening comprehension ability and find that this higher-order thinking instruction does improve students' listening comprehension ability. The findings indicate positive effects of metacognitive instruction through dialogic interaction on learners' multimedia listening comprehension and their metacognitive awareness in listening skill.

The reason that the results of the present study contradict previous studies may be due to high-proficiency trainees having become more deliberate in their learning and need to rely less on these metacognitive strategies. On the other hand, they may internalize and automatically use these metacognitive strategies in their learning as found in the study of Radwan (2011). These results indicate that high-proficiency trainees may not report on the high frequency of their higher order thinking. In other words, high proficiency students 
Table 1. Group comparisons of total metacognitive strategies in four English for domestic tourism lessons

\begin{tabular}{|c|c|c|c|c|c|}
\hline Lessons & Sum of squares & df & Mean square & $\mathbf{F}$ & Sig. \\
\hline \multicolumn{6}{|l|}{ Lesson one } \\
\hline Between groups & 1.84 & 1 & 1.84 & 3.76 & 0.07 \\
\hline Within groups & 7.82 & 16 & 0.49 & & \\
\hline Total & 9.66 & 17 & & & \\
\hline \multicolumn{6}{|l|}{ Lesson two } \\
\hline Between groups & 1.68 & 1 & 1.68 & 1.80 & 0.19 \\
\hline Within groups & 14.94 & 16 & 0.93 & & \\
\hline Total & 16.62 & 17 & & & \\
\hline \multicolumn{6}{|l|}{ Lesson three } \\
\hline Between groups & 1.39 & 1 & 1.39 & 1.38 & 0.26 \\
\hline Within groups & 16.19 & 16 & 1.01 & & \\
\hline Total & 17.53 & 17 & & & \\
\hline \multicolumn{6}{|l|}{ Lesson four } \\
\hline Between groups & 0.17 & 1 & 0.17 & 11 & 0.74 \\
\hline Within groups & 24.72 & 16 & 1.54 & & \\
\hline Total & 24.89 & 17 & & & \\
\hline
\end{tabular}

Table 2. Differences in the use of total metacognitive strategies in four English for domestic tourism lessons

\begin{tabular}{|c|c|c|c|c|c|c|c|c|}
\hline & \multirow[t]{2}{*}{$\mathbf{N}$} & \multirow[t]{2}{*}{ Mean } & \multirow[t]{2}{*}{$\begin{array}{l}\text { Standard } \\
\text { deviation }\end{array}$} & \multirow[t]{2}{*}{ Standard error } & \multicolumn{2}{|c|}{$\begin{array}{l}95 \% \text { confidence interval for } \\
\text { mean }\end{array}$} & \multirow[t]{2}{*}{ Minmum } & \multirow[t]{2}{*}{ Maximum } \\
\hline & & & & & lower bound & Upper bound & & \\
\hline \multicolumn{9}{|c|}{ Lesson one } \\
\hline Low & 9 & 3.38 & 0.68 & 0.22 & 2.86 & 3.91 & 2.25 & 4.50 \\
\hline High & 9 & 4.02 & 0.71 & 0.23 & 3.48 & 4.57 & 3.00 & 5.00 \\
\hline Total & 18 & 3.70 & 0.75 & 0.17 & 3.33 & 4.08 & 2.25 & 5.00 \\
\hline \multicolumn{9}{|c|}{ Lesson two } \\
\hline Low & 9 & 2.94 & 0.68 & 0.22 & 2.42 & 3.46 & 2.00 & 4.00 \\
\hline High & 9 & 3.55 & 1.18 & 0.39 & 2.64 & 4.46 & 1.00 & 4.75 \\
\hline Total & 18 & 3.25 & 0.98 & 0.23 & 2.75 & 3.74 & 1.00 & 4.75 \\
\hline \multicolumn{9}{|c|}{ Lesson three } \\
\hline Low & 9 & 2.83 & 0.96 & 0.32 & 2.09 & 3.57 & 1.00 & 3.75 \\
\hline High & 9 & 3.38 & 1.04 & 0.34 & 2.58 & 4.19 & 1.00 & 4.50 \\
\hline Total & 18 & 3.11 & 1.01 & 0.23 & 2.60 & 3.61 & 1.00 & 4.50 \\
\hline \multicolumn{9}{|c|}{ Lesson four } \\
\hline Low & 9 & 3.05 & 1.15 & 0.38 & 2.16 & 3.95 & 1.00 & 4.50 \\
\hline High & 9 & 3.25 & 1.32 & 0.46 & 2.23 & 4.26 & 1.00 & 4.50 \\
\hline Total & 18 & 3.15 & 1.21 & 0.28 & 2.55 & 3.75 & 1.00 & 4.50 \\
\hline
\end{tabular}

*H stands for high-proficiency group, L stands for low-proficiency group

probably use metacognitive strategies in their learning without them being aware of it, as they almost subconsciously use these strategies automatically.

The finding on indifferent use of metacognitive strategies was found in the study of Lam (2010). This author finds no significant difference in the use of metacognitive strategies between the two groups because the students are aware of their use of metacognitive strategies in their learning, particularly in the group-discussion task. The finding indicates the gradual increase of metacognitive strategies from the two groups from 15.60 percent to 35.30 percent for the first group and from 22.20 percent to 33.30 per cent for the latter group respectively. It is also claimed in this study that students should be taught to have a raised awareness of the use of metacognitive strategies by guiding their attention to the strategies that they find to be effective in their learning. Relationships in the four individual metacognitive strategies between two proficiency groups are displayed in the following table. 
Table 3. Group comparisons in the use of four individual metacognitive strategies

\begin{tabular}{|c|c|c|c|c|c|}
\hline & Sum of squares & df & Mean square & $\mathbf{F}$ & Sig. \\
\hline \multicolumn{6}{|l|}{ Assessment } \\
\hline Between groups & 1.00 & 1 & 1.00 & 1.34 & 0.26 \\
\hline Within groups & 11.93 & 16 & 0.74 & & \\
\hline Total & 12.93 & 17 & & & \\
\hline \multicolumn{6}{|l|}{ Goal setting } \\
\hline Between groups & 0.50 & 1 & 0.50 & 0.43 & 0.51 \\
\hline Within groups & 18.36 & 16 & 1.14 & & \\
\hline Total & 18.86 & 17 & & & \\
\hline \multicolumn{6}{|l|}{ Planning } \\
\hline Between groups & 1.25 & 1 & 1.25 & 1.42 & 0.25 \\
\hline Within groups & 14.09 & 16 & 0.88 & & \\
\hline Total & 15.35 & 17 & & & \\
\hline \multicolumn{6}{|c|}{ Control of linguistic execution } \\
\hline Between groups & 2.00 & 1 & 2.00 & 1.76 & 0.20 \\
\hline Within groups & 18.15 & 16 & 1.13 & & \\
\hline Total & 20.15 & 17 & & & \\
\hline
\end{tabular}

$* p<0.05$

Relationships between characteristics of the professional tour guide trainees and the use of metacognitive strategies in four English for Tourism lessons.

\section{Proficiency levels and metacognitive strategies use in four lessons}

Relationship between proficiency levels and four individual metacognitive strategies in each lesson is presented as below. Only the significant relationship between the two factors is presented.

The Chi-square tests reveal no significant relationship between proficiency level and the use of assessment strategy in the four lessons. This means that proficiency level is not related to the use of assessment strategy in learning English for Tourism. The result in in the four lessons are: lesson one, $X^{2}(3, \mathrm{~N}=18)=3.73, p=.29$, lesson two, $X^{2}(4, \mathrm{~N}=18)=4.28$, $p=0.36$, lesson three, $X^{2}(4, \mathrm{~N}=18)=4.44, p=.34$, lesson four, $X^{2}(4, \mathrm{~N}=18)=4.95, p=.29$.

As for goal setting strategy, the only significant relationship between proficiency level and the use of goal setting strategy is found in lesson four, presenting the northern attractions in Thailand. The results in the other three lessons are: lesson one, $X^{2}(2, \mathrm{~N}=18)=1.66, p=.43$, lesson two, $X^{2}(2, \mathrm{~N}=18)=2.73, p=.60$, lesson three, $X^{2}(4, \mathrm{~N}=18)=2.47$, $p=0.64$. Table 4 shows a significant relationship between proficiency level and goal setting strategy.

Table 4 shows that there is a significant relationship between the two proficiency groups and the use of goal setting strategy in lesson four, $X^{2}(4, \mathrm{~N}=18)=10.53, p=0.03$. This means that proficiency level is related to the use of goal setting strategy in learning the attractions presentation lesson.

It is noticeable that the high group reports high frequency of this strategy whereas the low group does not report anywhere close to this frequency at all (High group=five, Low group=none). However, more than half of the low group re- ports low to moderate frequency of this strategy (Low group $=$ two and three).

There is also no significant relationship between the two proficiency groups and the use of planning strategy in the four lessons, indicating that the use of planning strategy is not dependent on proficiency level. The results are: lesson one, $X^{2}(3, \mathrm{~N}=18)=3.64, p=0.30$, lesson two, $X^{2}(4, \mathrm{~N}=18$ ) $=7.33, p=0.11$, lesson three, $X^{2}(4, \mathrm{~N}=18)=2.73, p=0.60$, $\mathrm{p}=0.64$, lesson four, $X^{2}(4, \mathrm{~N}=18)=5.14, p=.27$.

Control of linguistic execution is significantly correlated with proficiency level only in lesson two, presenting Buddha images. The result in the other three lessons are: lesson one, $X^{2}(2, \mathrm{~N}=18)=3.61, p=.16$, lesson three, $X^{2}(4, \mathrm{~N}=18)=6.66$, $p=0.15$, lesson four, $X^{2}(4, \mathrm{~N}=18)=6.66, p=0.15$. Table 5 shows a significant relationship between proficiency level and the control of linguistic execution strategy in lesson two.

Table 5 shows that there is a significant relationship between the two proficiency groups and the use of control of linguistic execution strategy in lesson two, $X^{2}(4, \mathrm{~N}=18)=10.80$, $p=0.02$. This means that proficiency level is related to the use of control of linguistic execution strategy in presenting Buddha images lesson. It is noticeable that the high group solely reports high frequency of this strategy whereas the low group does not report in this frequency at all (High group=five, Low group=none). However, almost half of the low group reports high frequency of this strategy and also outnumbers the high group (High group=one, Low group $=$ four,). Results of the relationships between duration of English language study and individual metacognitive strategies use are presented as follows.

Results from the present study on significant relationships between some individual metacognitive strategies and proficiency levels correspond with the previous studies (Phaiboonnugulkij, 2016, Salahshour, Sharifi and Salahshour, 2013 and Radwan, 2011). These studies indicate 
significant relationship between proficiency levels and some individual metacognitive strategies as found in a study of Phaiboonugulkij (2016). The results indicate that there is a significant relationship among the four groups of students in some reported metacognitive strategies, $X^{2}(3, \mathrm{~N}=34)=17.09$, $p=0.01$. The significant relationship is evident in the use of sub-metacognitive strategies, particularly assessment and planning strategies in some lessons.

Salahshour, Sharifi and Salahshour (2013) and Radwan (2011) also reconfirm significant relationship between proficiency level and metacognitive strategies. The first study is conducted using 65 high- school students and the second study includes 128 English majored students that use English as a foreign language context. The results from both studies indicate that the more successful language learners make use of language learning strategies more frequently and effectively than the less successful learners. Among the language learning strategies, metacognitive strategies are also claimed by Oxford's (2003) as an important strategy for language learners which also found to be the most favored by the high-proficiency group. Relationships between duration of English language study and metacognitive strategies use are presented in the next section.

\section{Duration of English language study and metacognitive strategies use}

Duration of English language study is classified into three groups based on the years of English study from the trainees as prior mentioned in the participants section. The results from Chi-square test reveal no significant relationships between this factor and the use of assessment strategy in all four lessons, indicating that use of assessment strategy does not relate to duration of English language study. The results are: lesson one, $X^{2}(8, \mathrm{~N}=18)=7.84, p=.25$, lesson two, $X^{2}(8, \mathrm{~N}=18)=7.87, p=.44$., lesson three, $X^{2}(8, \mathrm{~N}=18)=3.23$, $p=0.91$, lesson four, $X^{2}(4, \mathrm{~N}=18)=8.39, p=0.39$.

Use of goal setting strategy is also not significantly related to duration in English language study across the four lessons. Chi-square results are: lesson one, $X^{2}(8, \mathrm{~N}=18)=4.53, p=.33$, lesson two, $X^{2}(8, \mathrm{~N}=18)=6.36, p=0.60$, lesson three $X^{2}(8$, $\mathrm{N}=18)=6.27, p=0.61$, lesson four, $X^{2}(4, \mathrm{~N}=18)=5.02, p=0.75$.

Unlike the two previous strategies, planning is significantly correlated to duration of English language study only in lesson three, presenting Thai history, meaning that the use of planning strategy relates to number of years in English language study in learning this lesson. The results are: lesson one, $X^{2}(6, \mathrm{~N}=18)=8.54, p=0.20$, lesson two, $X^{2}(6, \mathrm{~N}=18)=$ $8.57, p=0.38$, lesson four, $X^{2}(6, \mathrm{~N}=18)=2.66, p=0.95$. Table 6 shows a significant relationship between duration of English language study and planning strategy in lesson three.

Table 6 shows that there is a significant relationship between the duration in learning English language and the use of planning strategy in lesson three, $X^{2}(8, \mathrm{~N}=18)=21.42, p=.00$. This means duration in learning English language is related to the use of planning strategy in presenting Thai history lesson.

To be precise, professional tour guide trainees with less than 10 years report planning strategy from very low to high frequency (three, four, three, and four participants) where-
Table 4. Relationship between proficiency levels and goal setting strategy in lesson four

\begin{tabular}{lccc}
\hline & Value & df & Asymp. Sig. (2-sided) \\
\hline Pearson chi-square & $10.53^{\text {a }}$ & 4 & 0.03 \\
Likelihood ratio & 14.40 & 4 & 0.00 \\
Linear-by-linear & 0.23 & 1 & 0.62 \\
association & & & \\
N of valid cases & 18 & & \\
\hline
\end{tabular}

a. 10 cells $(100.0 \%)$ have expected count less than 5 . The minimum expected count is 1.00 .

Table 5. Relationships between proficiency level in English language and the use of control of linguistic execution strategy in lesson two

\begin{tabular}{lccc}
\hline & Value & df & Asymp. Sig. (2-sided) \\
\hline Pearson chi-square & $10.80^{\mathrm{a}}$ & 4 & 0.02 \\
Likelihood ratio & 14.40 & 4 & 0.00 \\
Linear-by-linear & 2.28 & 1 & 0.13 \\
$\begin{array}{l}\text { association } \\
\text { N of valid cases }\end{array}$ & 18 & & \\
\hline
\end{tabular}

a. 10 cells $(100.0 \%)$ have expected count less than 5 . The minimum expected count is 0.50 .

Table 6. Relationships between of English language study and planning strategy in lesson three

\begin{tabular}{lccc}
\hline & Value & df & Asymp. Sig. (2-sided) \\
\hline Pearson chi-square & $21.42^{\mathrm{a}}$ & 8 & 0.00 \\
Likelihood ratio & 11.83 & 8 & 0.15 \\
$\begin{array}{l}\text { Linear-by-linear } \\
\text { association }\end{array}$ & 1.80 & 1 & 0.17 \\
N of valid cases & 18 & \\
\hline $\begin{array}{l}\text { a. } 15 \text { cells (100.0\%) have expected count less than 5. The } \\
\text { minimum expected count is 0.06. }\end{array}$
\end{tabular}

as one trainee with experience between 11-20 years reports a very high use this strategy. For trainees with more than 21 years of experience, they moderately and highly use planning strategy (two and one participants) in this lesson.

Similar to planning strategy, control of linguistics execution strategy is only significantly correlated with duration of English language study only in lesson three, presenting Thai history, indicating that the use of control of linguistics execution relates to number of years in English language study in learning this lesson. Results from Chi-square test indicate no significant relationship of duration in learning English language study and this strategy in the rest three lessons. The results are: lesson one, $X^{2}(4, \mathrm{~N}=18)=8.02, p=.09$, lesson two, $X^{2}(8, \mathrm{~N}=18)=4.93, p=.76$, and lesson four, $X^{2}(6$, $\mathrm{N}=18)=5.09, p=.74$. Table 7 shows a significant relationship between duration of English language study and control of linguistics execution strategy in lesson three.

Table 7 shows that there is a significant relationship between the duration in English language learning and the use of control of linguistic execution strategy in lesson three, $X^{2}(8, \mathrm{~N}=18)=16.07, p=.04$. This means the amount of expe- 
Table 7. Relationships between of English language study and control of linguistics execution strategy in lesson three

\begin{tabular}{lccc}
\hline & Value & df & Asymp. Sig. (2-sided) \\
\hline Pearson chi-square & $16.07^{\mathrm{a}}$ & 8 & 0.04 \\
Likelihood ratio & 14.57 & 8 & 0.06 \\
Linear-by-linear & 0.07 & 1 & 0.78 \\
Association & & & \\
N of valid cases & 18 & & \\
\hline
\end{tabular}

a. 15 cells $(100.0 \%)$ have expected count less than 5 . The minimum expected count is 0.11 .

rience is related to the use of control of linguistic execution strategy in presenting Thai history lesson.

Adding to this majority of professional tour guide trainees with less than ten years highly report control of linguistic execution strategy (six participants) and the rest variedly report this strategy from very low, low and very high frequency (two, two, and three participants). It is noticeable that only one trainee in this group moderately uses this strategy while all of trainees with experience more than 21 years use this strategy moderately (three participants). One trainee with experience between 11-20 years very highly report this strategy.

Results of the present study clearly show that professional tour guide trainees with the lowest duration in English language learning significantly report the highest frequency of both planning and control of linguistic execution in some lessons which are pertinent to the study of Radwan (2011). The author investigated the relationship between duration in English language study and choice of learning strategy as part of the study. To be precise freshmen report higher use of metacognitive strategy $(\mathrm{M}=4.04)$, followed by Junior $(M=3.89)$, Sophomore $(M=3.78)$ and Senior $(M=3.70)$.

For the duration of study and frequency of strategy use, it is purported in Radwan's study that the more students advanced in the target language, the need to use their learning strategy consciously, becomes less necessary. They may internalize these strategies, and these strategies are autonomously processed, thus the senior learners reported less use of strategy than that of the freshmen group. Results of the relationships between of jobs and individual metacognitive strategies use are presented as follows.

\section{Types of jobs and metacognitive strategies use}

Results from Chi-square test show no significant relationship between four types of job and the four individual metacognitive strategies across the four lessons. This means that use of these strategies does not depend on any types of jobs. Although no significant correlation is found, the use of assessment strategy in lesson three, presenting Thai history, contains the highest correlation among all the four individual strategies across four lessons.

Results for assessment strategy are: lesson one, $X^{2}(9$, $\mathrm{N}=18)=13.33, p=.14$, lesson two, $X^{2}(12, \mathrm{~N}=18)=17.71$, $p=.12$, lesson three, $X^{2}(12, \mathrm{~N}=18)=20.38, p=.06$, and lesson four, $X^{2}(12, \mathrm{~N}=18)=9.35, p=.67$. The results in lesson three reveal the highest correlation in all of the individual strategies in the four lessons. Chi-square results show that almost all the tour guides in this group report highest frequency in moderate category, followed by very low and high respectively (seven, one and one participants).

As for tourism staff group, half of them use this strategy with a low frequency, and they use assessment strategy in very low, moderate and high frequency in lesson three (three, one, one and one participants). A marketing manager moderately use assessment strategy whereas students highly and very highly report assessment strategy (one and one participants).

Similarly, goal setting strategy results are: lesson one, $X^{2}(6, \mathrm{~N}=18)=5.25, p=.51$, lesson two, $X^{2}(12, \mathrm{~N}=18)=13.60$, $p=.32$, lesson three, $X^{2}(12, \mathrm{~N}=18)=9.27, p=.67$, and lesson four, $X^{2}(12, \mathrm{~N}=18)=15.73, p=.20$. Moreover, results for planning strategy are: lesson one, $X^{2}(9, \mathrm{~N}=18)=7.00, p=.63$, lesson two, $X^{2}(12, \mathrm{~N}=18)=15.50, p=.21$, lesson three, $X^{2}(12$, $\mathrm{N}=18)=8.61, p=.73$, and lesson four, $X^{2}(12, \mathrm{~N}=18)=10.10$, $p=60$. Finally, results of control of linguistics execution strategy are: lesson one, $X^{2}(6, \mathrm{~N}=18)=6.88, p=.33$, lesson two, $X^{2}(12, \mathrm{~N}=18)=10.01, p=.61$, lesson three, $X^{2}(12, \mathrm{~N}=18)$ $=14.33, p=.28$, and lesson four, $X^{2}(12, \mathrm{~N}=18)=11.02, p=.52$.

Results on no significant relationship between types of job and use of metacognitive strategies as found in the present study may be due to the awareness in the use of metacognitive strategy in line with the knowledge in specific features of English language use in an LSP setting, particularly, in English for Tourism context. When the learners with difference in types of jobs master these notions in learning LSP, they might not report different frequency of metacognitive strategies across the lessons as found in the results from the precious study of Phaiboonnugulkij (2016). Following part presents the qualitative content analysis from the coding scheme.

\section{Qualitative content analysis from the coding scheme}

This section presents qualitative content analysis from the coding scheme on the use of four individual metacognitive strategies based on English proficiency level, duration in English language study and types of job. The information on the use of these strategies is presented in four English for Tourism lessons: assessment, goal setting, planning, and control of linguistic execution.

The first letter " $H$ " and " $L$ " refer to high- and low-proficiency of the participants while the number means the number of the participants. The last letter "L" means the lesson, followed by the number of that lesson. The individual strategies that are significantly and differently used and correlated to the factors in this study are presented in details as follows.

\section{Proficiency levels}

Assessment strategy is mainly used in lesson one, presenting general information through self-assessment by majority of the high-proficiency group. They also assess information and content to be used in their presentation. On the contrary, 
almost all of the low-proficiency group mainly assesses information and background knowledge to present general information about Thailand. Followings are some examples. In lesson two, assessing specific details is mainly used by the high-proficiency group. The high-proficiency group solely assess background knowledge in presenting Thai history. There is no prominent way to use this strategy in lesson four. Following are some examples.

Self-assessment

H5L1: I review (my) background knowledge for make a self-assessment and identify the knowledge in groups by making a list.

Assessing information, content and background knowledge

H6L1: I assess the information. For example, Thailand is locked in the center of Southeast Asia, known as the gateway of Indo-China. The neighboring countries are Laos, Myanmar, Cambodia and Malaysia.

H8L3: I have some background knowledge and expect the teacher is going to teach by using VDO presentation.

L1L1: I assess the lesson so I have knowledge about tourism correctly

Describe specific details

H3L2: My purpose is to make sure the tourist knows the name of the attitude of the Buddha image.

Goal setting strategy is mainly employed by the high-proficiency group to identify the background content knowledge and information to present general information about Thailand. Similarly, almost all of the low-proficiency group also identifies the content knowledge and information to achieve their goal. They also set the goal to find more information and explain it to the foreign tourist accurately.

In lesson two and three, there are not many differences in the use of this strategy. However, the prominent way in using goal setting is in lesson four that the high-proficiency students to tell the interesting attractions. They expect to understand the step-in presentation. They hope to know authentic things to present the attraction. Similarly, the low-proficiency group also set their goal to get authentic knowledge, present the content and understand the information. Examples are as follows.

Tell the interesting attractions

H6L4: I hope I can give interesting information about tourist attraction in the north of Thailand to the tourist in a simple and easy to understand way.

Understand the step and content in presentation

H7L4: I have to understand more about the information of the north and know the steps to explain.

L6L4: I must understand more about the information of the north and know their history.

Know authentic things to present the attraction

H8L4: I expect to use the authentic things for learning and present.

L4L4: I hope to get the authentic knowledge correctly.

Present the content

L5L4: I will present contents about clothes and food.

Planning strategy is used by the majority of the high-proficiency group to plan to search for more information to present general information about Thailand. Adding to this, majority of them plan to review vocabulary and key information to present Thailand. Some of them plan the structure for this purpose. Similar to the high-proficiency group, majority of the low-proficiency group plans the content for presenting Thailand. Some of them also plan vocabulary, structure and pronunciation. In lesson two, find specific vocabulary, structure and information whereas in lessons three and four, the high-proficiency group plan to explain the history in a simple way. Following are some examples.

Plan to search more information

H6L1: I've planned about writing by using order thinking from general to specific and concluding by using the pattern you've learned.

H2L2: I plan and read the vocabulary and know the meaning. Study the structure before learning.

L3L1: I plan to explain how it is important before and after.

Plan to review vocabulary and key information

H3L1: I plan and use vocabulary about travel, distance, time, restaurant, and hotel. Start, I think of finish, where we have lunch? breakfast? dinner?

L6L1: I search the vocabulary before learning.

Control of linguistic execution strategy is prominently used in lesson 2 by the high-proficiency group to think of content to use to describe the Buddha image. Only one of them thinks of language structure to use in this lesson. On the contrary, one of the low-proficiency group uses the content in real life for their profession. One of them adapt the content and structure to study this lesson. Followings are some examples.

Use language to describe the Buddha image

H3L2: I think of the language to use:

-When does the attitude of the Buddha image happen?

-Who does the attitude of the Buddha image build?

-Where does the attitude of the Buddha image locate?

-How is the important of the attitude of the Buddha image?

Use structure to describe the Buddha image

H6L2: I've used language structure cooperate with content to describe the Buddha image suitably.

Adapt the content and structure

L4L2: I adapt the content to match the structure appropriately.

Use language in real life

L9L2: I think the content can be used in real life.

Details about use of individual metacognitive strategies categorized by duration in English language study are as follows.

\section{Duration in English language study}

Assessment strategy is mainly used by group one across four lessons through self-assessment by majority of the first group. This group also assessed information and content to be used in their presentation. This includes assessing information and background knowledge to present information about Thailand. Similarly, the second and third groups rely mainly on assessing information and background knowledge. Followings are some examples

Duration less than 10 years

Assessing information, content and background knowledge H7L1: I assess types of information. For example, Thailand is the third biggest country in Southeast Asia, our neighbor is Myanmar, Laos, Cambodia and Malaysia 
Duration more than 21 years

H4L1: I assess whether I can use the knowledge that has learned to apply in work.

L4L2: I assess that get the basic information from other material.

Goal setting strategy is mainly employed by the first and second group to identify the background content knowledge and information to present information about Thailand. The first group also set a goal to get the required information in this lesson and how to write the script for presentation accurately. Interestingly, the majority of the third group set a goal to get the information and explain it to the foreign tourist accurately. Examples are as below.

Duration less than 10 years

Identify the background content knowledge and information to achieve their goal

H7L1: Before start learning, we already know information about Thailand. And then we have to know the purpose of what we are learning for applying with the old knowledge.

H7L2: I planned to explain about Buddha image from where it starts.

Duration more than 21 years

Apply knowledge in their work

H4L1: I set goals to apply in work and studying.

Give information

L4L1: I can explain the information about the temple in Thailand.

L4L3: I begin from creator, who, what, where.

Planning strategy is used by all the three groups to plan to search more information to present general information about Thailand. It is noticeable in the third group that one of the students planned the content to present, specifically about the elements of Thai temples. It is prominent in lesson three that the first group planned to present the history and explain the history in simple way. Similarly, the third group plans to find more information from the book and the content. Followings are some examples.

Duration less than 10 years

Plan the content

L4L1: I plan for other elements in temple in Thailand.

Present the content of the history

L4L1: I begin from creator, who, what, where.

Read and find more information about Thai history

L8L3: I will read books and take note while teacher is teaching.

Duration more than 21 years

Present the content of the history

L4L3: I begin from creator, who, what, where.

Control of linguistic execution strategy is employed by most of the first group to use the language structure with appropriate content. It is prominently used in lesson three, presenting Thai history. It is only found in the second group that the student controlled the language from the beginning until the end. Similarly, only the third group uses the vocabulary to present Thai history. Followings are some examples.

Duration less than 10 years

Use sentence structure with appropriate content
H4L3: I control and use knowledge to present information of places and history.

Use content

L4L1: I control the content in that place and history.

Duration between 11-20 years

Control the language from the beginning until the end

H7L3: I control all the language and structure so that I can explain about the history of Thailand from the beginning until the end to the tourist.

Duration more than 21 years

Use vocabulary correctly

L4L3: I use word correctly and have reference.

\section{CONCLUSIONS}

This study aims to investigate and compare total and individual metacognitive strategies used by professional tour guide trainees in four English for Tourism lessons, and explore the relationships between the use of metacognitive strategies in these lessons and characteristics of professional tour guide trainees. The results show that the high- and low- proficiency group do not significantly and differently report the total and the individual metacognitive strategies across the four English for Tourism lessons.

Relationships between characteristics of the English language learners and use of metacognitive strategies are found in proficiency levels and duration of English language study in some individual metacognitive strategies in particular lessons. Proficiency levels are significantly correlated with goal setting strategy in presenting northern attractions while a significant relationship is also found with control of linguistic strategy in presenting Buddha images.

It is noticeable in this study that participants with the lowest duration in English language study report the highest frequency of metacognitive strategies which may be due to awareness and automatic use of these metacognitive strategies in their learning of the more advanced in duration in English language that they report lower frequency as the lowest duration group. However, there is no significant relationship between types of jobs and use of metacognitive strategies.

The statistical results and insight details from content analysis of the present study and the previous studies, metacognitive strategies are significant in English language learning, specifically, LSP context. Knowing the specific feature of this type of language and the way to utilize these metacognitive strategies could help the learners to achieve their specific context learning.

It is also significant that learners should be trained to be aware of their metacognitive strategies use and should be guided to employ metacognitive strategies to fit with their learning for improving their learning regardless of duration in English language study as seen in the results of this study. The way to utilize metacognitive strategies should also be implemented in the continuum of instruction from the course outline, instructional materials and approaches to support all learners to personalize, self-manage and self-control their learning at their preference and to their fullest potential. 


\section{ACKNOWLEDGEMENTS}

The author would like to thank Faculty of Humanities and Social Sciences from Nakhon Ratchasima Rajabhat University for providing research grant to conduct this study.

\section{REFERENCES}

Bozorgian, H., and Alamdari, E. F. (2018). Multimedia listening comprehension: Metacognitive instruction or metacognitive instruction through dialogic interaction. ReCALL, 30(1), 131-152.

Deneme, S. (2008). Language learning strategy preferences of Turkish students. Journal of Language and Linguistic Studies, 4(2),83-93.

Douglas, D. (2000). Assessing languages for specific purposes. Cambridge: Cambridge University Press.

Khamkhien, A. (2010). Factors affecting language learning strategy reported usage by Thai and Vietnamese EFL learners. Electronic Journal of Foreign Language Teaching, 7, 1: 66-85.

Kunasaraphan, K. (2015). English learning strategy and proficiency level of the first-year students. Procedia-Social and Behavioral Sciences, 197(19), 1853-1858.

Lam, W.Y.K. (2010). Implementing communication strategy instruction in the ESL oral classroom: What do low-proficiency learners tell us? TESL Canada Journal, 27(2), 11-30.

Liu, Y., and Feng H. (2011). An empirical study on the relationship between metacognitive strategies and online-learning behavior \& test achievements. Journal of Language Teaching and Research,2(1),183-187. [Online] Available: http://dx.doi.org/11.5679/elt.v7n6g7h13 (May 22, 2015)
Oxford, R. L. (2003). Language learning styles and strategies: An overview. Learning Styles \& Strategies/Oxford, GALA, 1-25.

Phaiboonnugulkij, M. and Prapphal, K. (2013). Online speaking strategy assessment for improving speaking ability in the area of language for specific purposes: The case of tourism. English Language Teaching, 6(9), 19-29.

Phaiboonnugulkij, M. (2015). Insights into InConMedt: A practical guideline. Pertanika Journal of Social Sciences and Humanities (JSSH), 23(4), 1179 - 1192.

Phaiboonnugulkij, M. (2016). Tap into Students' Metacognitive Strategies Report via the Internet-Mediated Contextualized English for Domestic Tourism Lessons (InConMedt). International Journal of Applied Linguistics and English Literature, 5(2), 171-182.

Pitenoee, M. R., Modaberi, A., and Ardestani, E. M. (2017). The Effect of Cognitive and Metacognitive Writing Strategies on Content of the Iranian Intermediate EFL Learners' Writing. Journal of Language Teaching and Research, 8(3), 594-600.

Radwan, A. A. (2011). Effects of L2 proficiency and gender on choice of language learning strategies by university students majoring in English. The Asian EFL Journal Quarterly March 2011, 13(1).

Salahshour, F., Sharifi, M., and Salahshour, N. (2013). The relationship between language learning strategy use, language proficiency level and learner gender. Procedia-Social and Behavioral Sciences, 70, 634-643.

Zhou, Z. (2018). On the Relationship of Students'English Learning Beliefs and Learning Strategy in the University. Journal of Language Teaching and Research, 9(1), 175-180. 